\title{
Perancangan Desain Pengembangan Industri Makanan Tradisonal Minangkabau yang Berdaya Saing Global
}

\author{
Eka Rosalina1, Afridian Wirahadi Ahmad² \\ 1 Jurusan Akuntansi, Politeknik Negeri Padang \\ Email:ekarosalinapnp5@gmail.com \\ ${ }^{2}$ Jurusan Akuntansi, Politeknik Negeri Padang \\ Email: afridianpadang@gmail.com
}

\begin{abstract}
ABSTRAK
This study aims to discuss the design strategy of traditional minangkabau food development in West Sumatra Province and to provide policy recommendation for traditional minangkabau food to be globally competitive. Tourism in the Minangkabau region is known in three things: culinary tourism (traditional food), nature tourism and cultural tourism. Ideally, whatever the destination in West Sumatra, each region always highlight the uniqueness of traditional food, but it is difficult to find traditional minangkabau food, especially in tourist areas. Culinary business that grow precisely fast food. The study was conducted on all regencies / cities in West Sumatra. Data collection techniques through interviews and questionnaires and FGDs. The data analysis was performed by IFAS analysis tool, EFAS.
\end{abstract}

Keywords: Traditional Food, Desian Model Development.

Penelitian ini bertujuan untuk membahas strategi desain pengembangan makanan tradisional minangkabau di Propinsi Sumatera Barat serta memberikan rekomendasi kebijakan agar makanan tradisional minangkabau berdaya saing global. Wisata di daerah Minangkabau dikenal dalam tiga hal yakni wisata kuliner (makanan tradisional), wisata alam dan wisata budaya. Idealnya, apapun daerah tujuannya di Sumatera Barat, masing-masing daerah selalu menonjolkan keunikan makanan tradisionalnya, namun yang terjadi sulit menemukan makanan tradisional minangkabau khususnya di daerah tempat wisata. Usaha kuliner yang tumbuh justru makanan cepat saji. Penelitian dilakukan terhadap seluruh kabupaten/kota di Sumatera Barat. Teknik pengumpulan data melalui wawancara dan kuesioner serta FGD. Analisa data dilakukan dengan alat analisis IFAS, EFAS.

Kata kunci : Makanan Traditional, Desian Model Pengembangan.

\section{Pendahuluan}

Makanan indonesia merupakan pencerminan beragam budaya dan tradisi berasal dari kepulauan nusantara Indonesia yang terdiri dari berbagai kepulauan dan propinsi yang ada di seluruh nusantara. Pada dasarnya tidak hanya satu bentuk tunggal tetapi lebih kepada, keanekaragaman masakan regional yang dipengaruhi secara lokal oleh Kebudayaan Indonesia. Seiring dengan berkembangnya industri pariwisata dan meningkatnya kompetisi antar daerah dalam menarik minat wisatawan, wisata kuliner menjadi hal yang menjadi perhatian utama oleh pemerintah, investor dan wisatawan itu sendiri. Makanan tradisional atau Gastronomi (tata boga) merupakan salah satu budaya lokal yang mempunyai peranan penting karena dapat menjadi pusat pengalaman wisatawan. Beberapa daerah tujuan wisata menggunakan gastronomi sebagai alat penarik wisatawan dan menggunakan pariwisata untuk promosikan gastronominya. 
Pembentukan Kementerian Pariwisata dan Ekonomi Kreatif serta telah disusunnya Rencana Pengembangan Ekonomi Kreatif Indonesia 2025 merupakan salah satu bukti nyata dukungan pemerintah terhadap industri kreatif di Indonesia. Disamping itu, kolaborasi antara pemerintah, akademisi dan bisnis menjadi mutlak dan merupakan prasyarat mendasar (Departemen Perdagangan RI, 2008) untuk mewujudkan visi ekonomi kreatif Indonesia 2025 yaitu "Bangsa Indonesia yang berkualitas hidup dan bercitra kreatif di mata dunia". Jika dihubungkan dengan upaya pemerintah Indonesia yang sedang gencar mewujudkan visi Indonesia kreatif 2025 dan mempromosikan pariwisata, maka kekayaan makanan tradisional unggulan menjadi hal sangat berharga untuk dikembangkan. Banyak contoh negara-negara lain memperkenalkan pariwisatanya melalui kulinernya seperti Malaisya, Thailand, Jepang, Perancis, Italia dan lainnya.

Salah satu daerah yang sangat terkenal akan masakan nya adalah daerah Sumatera Barat yang biasa juga di sebut dengan daerah Minangkabau. Cukup terkenalnya makanan Minangkabau ini dikarenakan menggunakan bumbu dan rempah yang sulit di tiru oleh daerah lain maupun negara lain. Ironisnya di daerah Minangkabau itu sendiri, banyak sekali bermunculan makanan makanan cepat saji dan cafe-cafe, hotel dan tempat wisata yang tidak lagi menyajikan makanan tradisonal yang merupakan warisan nenek moyang Minangkabau. Berkembangnya jumlah wisatawan di Sumatera barat harus menjadi perhatian penting bagi pemerintah dan pelaku usaha untuk mengenalkan lebih dalam terkait kuliner tradisional Minangkabau.

Dalam paparan latar belakang, permasalahan yang dapat dirumuskan adalah : Bagaimana startegi perancangan pengembangan makanan tradistional Minangkabau yang berdaya saing global?.

\section{Tinjauan Pustaka}

\section{Pengertian Strategi}

Stanton (1996 : 40) menyatakan bahwa strategi adalah sebuah rencana dasar yang luas dari suatu tindakan organisasi untuk mencapai tujuan. Menurut Stoner dkk (1995 dalam Tjiptono 2002:3) mendefinisikan bahwa strategi dibedakan atas dua perspektif yang berbeda, yaitu perspektif apa yang ingin dilakukan oleh organisasi (intend to do) dan apa yang akhirnya dilakukan oleh organisasi (eventually does). Berdasarkan perspektif yang pertama, strategi dapat didefinisikan sebagai program untuk menentukan dan mencapai tujuan organisasi dalam mengimplementasikan misinya. Makna yang terkandung dari strategi ini adalah para manager memainkan peran yang aktif, sadar dan rasional dalam merumuskan strategi organisasi. Perspektif yang kedua, strategi didefinisikan sebagai pola tanggapan atau respon organisasi terhadap lingkungannya sepanjang waktu. Pada definisi ini setiap organisasi pasti memiliki strategi, meskipun strategi tersebut tidak pernah dirumuskan secara eksplisit. Pandangan ini diterapkan bagi para manager yang bersifat reaktif, artinya menanggapi dan menyesuaikan diri terhadap lingkungan secara pasif.

Berdasarkan definisi diatas maka disimpulkan strategi yang dimaksud dalam penelitian ini adalah kesatuan rencana yang komprehensif dan terpadu untuk mencapai keunggulan bersaing dalam mencapai tujuan yang diwujudkan dalam bentuk program-program pengembangan. Dalam hal ini pengembangan makanan 
tradisional unggulan Minangkabau untuk mampu bersaing dengan makananmakanan dari negara lain, setidaknya mampu menjadi tuan rumah didaerah sendiri yaitu Sumatera Barat.

\section{Pengertian Pengembangan Produk}

Pada dasarnya pengembangan produk adalah usaha yang dilakukan secara sadar dan berencana untuk memperbaiki produk yang sedang berjalan atau menambah jenis yang sudah ada. Menurut Kotler (2002:3) produk memiliki pengertian yang luas yaitu segala sesuatu yang ditawarkan, dimiliki, digunakan, atau dikonsumsikan sehingga dapat memuaskan keinginan dan kebutuhan termasuk didalamnya adalah fisik, jasa, orang, tempat, organisasi serta gagasan. Pengembangan produk baru sangat membentuk masa depan perusahaan.

Kotler (1997:300) menyatakan bahwa pengembangan produk atau produk baru dapat memberikan dua macam sumbangan keuntungan. Pertama, apabila pengembangan produk atau produk baru itu berhasil diterima oleh konsumen maka laba perusahaan akan meningkat. Yang kedua, apabila proses pengembangan produk baru berhasil maka perusahaan akan membentuk suatu organisasi yang lebih efektif ketika akan melaksanakan proses pengembangan produk selanjutnya.

Menurut Buchari(2000) tujuan pengembangan produk adalah:(1 )untuk memenuhi keinginan konsumen yang belumpuas, (2)untuk menambah omzet penjualan, (3) untuk memenangkan persaingan, (4) untuk mendayagunakan sumber-sumber produksi, (5) untuk meningkatkan keuntungan dengan pemakaian bahan yang sama, (6) untuk mendayagunakan sisa-sisabahan, (7)untuk mencegah kebosanan konsumen, dan (8) untuk menyederhanakan produk, pembungkus.

\section{MakananTradisional Minangkabau}

Makanan tradisional atau khas adalah makanan dan minuman yang biasa dikonsumsi oleh masyarakat tertentu, dengan citarasa khas yang diterima oleh masyarakat tersebut. Berdasarkan Kamus Besar Bahasa Indonesia (2014) tradisional memiliki makna sebagai sesuatu yang sifatnya turun temurun dan menurut ada suatu daerah atau kawasan, sedangkan makanan memiliki arti sesuatu yang dimasukkan melalui mulut yang berfungsi memberi nutrisi kepada tubuh sehingga pengertian makanan tradisional secara sederhana berarti sebagai segala sesuatu yang dikonsumsi masyarakat suatu daerah secara turun temurun guna memenuhi kebutuhan nutrisibagi tubuhnya. Menurut Ernayanti (2003;2) dalam Ensiklopedi Makanan Tradisional di Pulau Jawa dan Pulau Madura memberikan pengertian tentang makanan tradisional memiliki nilai budaya, tradisi, serta kepercayaan yang bersumber pada budaya lokal (local indigenous).

\section{Daya Saing}

Daya saing ialah kemampuan sebuah bangsa untuk tumbuh dan berkembang secara normal di antara bangsa-bangsa lain dalam iklim kompetitif. Berdaya saing di sini bagaimana strategi pemasaran, layanan purnajual, harga yang kompetitif dan lain-lain merupakan kalsium untuk memperkokoh kerangka kebersaingan, umpama terkait produk tertentu.Produk makanan traditional Minangkabau harus mampu dalam menghadapi persaingan dengan kota lainnya maupun negara lainnya. 


\section{Metode Penelitian}

\section{Lokasi Penelitian dan Responden}

Adapun lokasi penelitian pada tahun kedua terpilih adalah

a. Kota Padang. Kota Padang dipilih selain ibukota propinsi Sumatera Barat, namun juga pusat perdagangan dan penginapan wisatawan. Sehingga di Kota ini, peneliti melakukan berbagai instrumen untuk memperoleh model pengembangan makanan tradisional sebagai oleh-oleh atau cenderamata bagi wisatawan.

b. Kota Bukittinggi. Kota ini dipilih karena merupakan kota pusat wisata minangkabau. Fokus penelitian dikota ini adalah mengujicobakan model yang dirancang untuk makanan yang disajikan langsung (wisata kuliner) minangkabau.

c. Kota Sawahlunto. Kota ini dipilih mewakili kota/kabupaten lainnya yang tidak banyak memiliki objek wisata andalan dan minimnya jumlah penginapan. Pada kota ini akan dilakukan berbagai metode mendorong semakin dikenalnya makanan tradisional unggulan Sumatera Barat.

\section{Pengumpulan Data}

Teknik pengumpulan data yang digunakan adalah desk study untuk data sekunder dan untuk data primer melakukan observasi, wawancara, kuesioner dan focus group discussion (FGD). Disamping itu, pengumpulan data juga dilakukan dengan wawancara mendalam dengan aparat pemerintah, masyarakat dan wisatawan terkait terutama makanan tradisional yang memiliki potensi unggulan dan dapat dikembangkan. Terakhir dilakukan survey lapangan ke seluruh daerah yang menjadi basis industri makanan tradisional unggulan yang dapat dikembangkan.

\section{Teknik Analisis Data}

\section{Analisis Faktor internal dan eksternal}

Analisis lingkungan dimaksud untuk mencoba mengidentifikasi kekuatan (strenghts) dan peluang (opportunities) yang perlu segera mendapatkan perhatian dan pada saat yang sama diarahkan untuk mengetahui kelemahan(weaknesses) dan ancaman (threats) yang perlu mendapatkan antisipasi (Suwarsono, 1998).

\section{Analisisinternal}

Tabel IFAS (Internal Factor Analisys Strategy) disusun untuk merumuskan faktorfaktor strategis internal. Penafsiran atas keterangan responden menjadi hasil identifikasi kekuatan dan kelemahan. Kekuatan dan kelemahan tersebut kemudian dianalisis internal dengan menggunakan matrik IFAS. Matrik IFAS digunakan untuk menganalisis faktor internal yang dilakukan untuk mendapatkan faktor kekuatan dan faktor kelemahan yang telah dianti sipasi kekeberadaannya. Kemudian faktor kekuatan dan kelemahan itu diberi bobot dengan nilai 0 (kurang penting), 1 (sama penting) dan 2 (lebih penting). Setelah dirata-rata maka total bobot nilai sama dengan 1. Selanjutnya, menghitung peringkat/rating dari masing-masing faktor dengan nilai 4 (sangat kuat), 3 (kuat), 2 (sedang) dan 1 (lemah). Menghitung skor pada kolom empat dengan cara mengalikan bobot dengan rating. Untuk mendapatkan skor total dengan cara menjumlahkan semua skor. Jika nilainya di bawah 2,50 maka berarti secara eksternal adalah lemah dan nilai skor diatas 2,50 menunjukkan posisi eksternal yang cukup kuat. 


\section{Analisis eksternal}

Matrik evaluasi faktor eksternal (EFAS) memungkinkan para penyusun strategi untuk merangkum dan mengevaluasi informasi ekonomi, sosial, budaya, demografi, lingkungan, politik, pemerintah, hukum, teknologi, dan persaingan (David,2006: 143). Penafsiran atas keterangan respon den menjadi hasil identifikasi peluang dan ancaman. Peluang dan ancaman tersebut kemudian di analisis eksternal dengan menggunakan Matrik EFAS. Hasil analisis eksternal dilanjutkan dengan mengevaluasi guna mengetahui apakah strategi yang dipakai selama ini memberikan respon terhadap peluang dan ancaman yang ada. Untuk maksud tersebut digunakan Matrik EFAS (External Factor Analysis Strategi), dengan langkah-langkah seperti; membuat matrik yang terdiri dari empat kolom, dan member bobot pada semua faktor peluang dan ancaman dengan nilai 0 (kurang penting), 1 (sama penting) dan 2 (lebih penting) dan lebih lanjut dirata-rata maka jumlah bobot nilai sama dengan 1 pada kolom dua. Dalam menghitung peringkat/rating masing-masing faktor dengan nilai 4 (sangat kuat), 3 (kuat), 2 (sedang) dan 1 (lemah). Untuk mendapatkan skor pada kolom empat, dengan cara mengalikan bobot pada kolom dua dengan rating pada kolom tiga.Masing-masing faktor yang ada skornya dijumlahkan dan bila mendapatkan jumlah total skor dibawah 2,5 artinya secara eksternal adalahlemah, sedangkan bila diatas 2,5 menunjukkan posisi eksternal yang cukup.

Teknik analisa tergambar dalam :

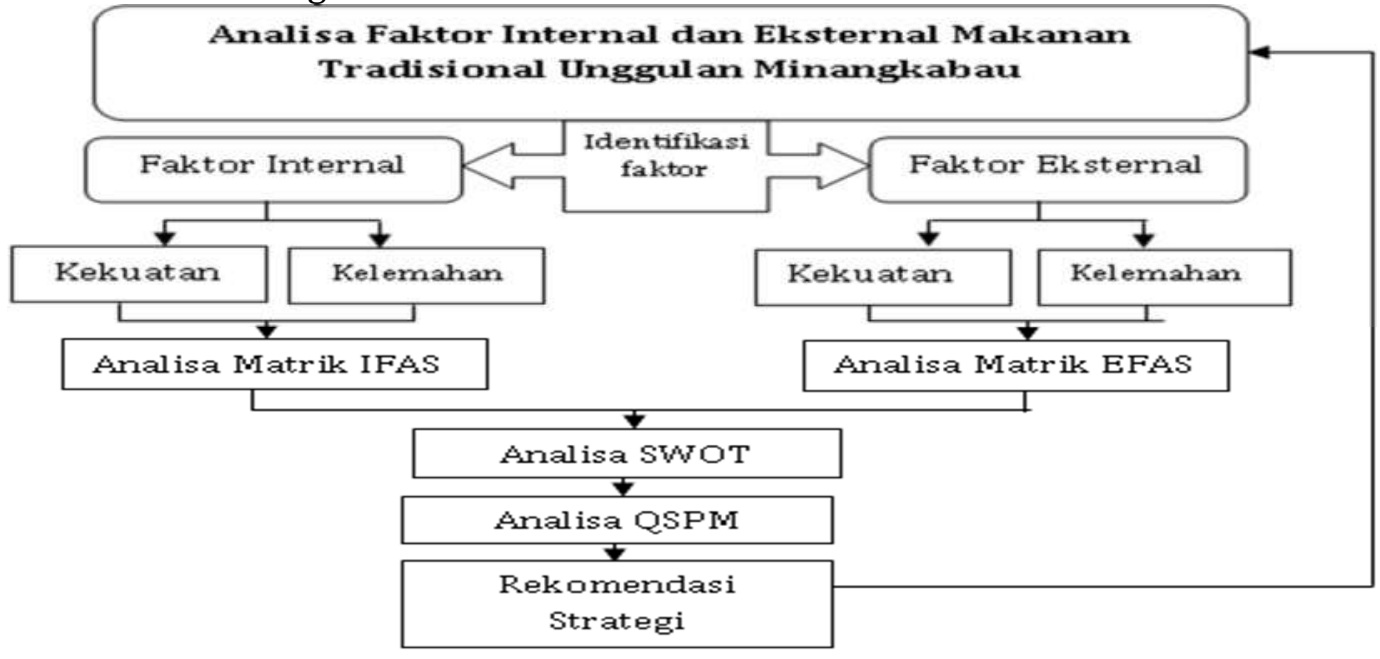

\section{HASIL DAN PEMBAHASAN}

Penelitian ini bertujuan M engumpuKan data dibeberapa daerah yang menjadi objek penelitian di Sumatera Barat teknik wawancara terhadap wisatawan dan pelaku usaha untuk mengidentifikasi desian apa yang pantas untuk di lakukan dalam menghadapi persaingan global.

Strategi desain pengembangan antara lain :

1. Meningkatkan promosi makanan tradisional Minangkabau .

a. Pengiklanan. Pengiklanan merupakan informasi yang diberikan produsen kepada konsumen dengan semenarik mungkin agar konsumen merasa ingin memiliki produk tersebut. Iklan dapat dipasang pada media massa seperti 
televisi, surat kabar, majalah, ataupun melalui internet dengan memanfaatkan kerjasama teknologi digital melaluiwebsite.

b. Personalselling. Dalam personal selling terjadi interaksi langsung saling bertemu muka antara pembeli dengan penjual komunitas yang dilakukan keduabelah pihak, bersifat individu dan dua arah sehingga penjual dapat langsung memperoleh tangga panse bagai umpan Minangkabau tentang keinginan dan kesukaan pembeli, penyampaian berita atau percakapan sangat fleksibel karena dapat menyesuaikan dengan kondisi yang ada. Didalam restoran pramusaji dapat meningkatkan penjualan melalui hubungan dengan para tamu. Pramusaji dapat memberikan saran, mengingatkan, dan membantu konsumen dalam menentukan pilihannya.

2. Mengembangkan outlet-outlet makanan tradisional Minangkabau dalam hotel dan tempat wisata alam.

a. Membuka autlet khusus makanan tradisional Minangkabau sehingga para tamu mengetahui keberadaan makanan tradisional Minangkabau dalam hotel.

b. Menawarkan berbagai jenis produk makanan tradisional Minangkabau yang sesuai dengan gastronomi internasional.

3. Meningkatkan dan menjaga imejkualitas produk dan keamanan makanan tradisional Minangkabau.

a) Meningkatkan kualitas kebersihan dan kesehatan produk makanan tradisional Minangkabau. Dalam dunia kuliner masalah kebersihan dan kesehatan makanan merupakan suatu hal yang sangat penting untuk diperhatikan selain cara pengolahannya. Makanan yang bersih dan sehat akan dapat meminimalkan terjadinya keracunan makanan bagi yang menikmatinya. Jika hal ini terjadi tentunya akan dapat menimbulkan hal negatif bagi wisatawan terhadap makanan tradisional Minangkabau.

b) Bekerja sama dengan pelaku pariwisata lainnya dalam memberikan informasi yang jelas mengenai makanan tradisional Minangkabau kepada wisatawan. Informasi mengenai makanan tradisional Minangkabau sangat penting untuk diketahui oleh wisatawan sehingga tidak menimbulkan persepsi yang berbeda mengenai makanan Minangkabau itusendiri. Banyak wisatawan mengira bahwa semua makanan tradisional Minangkabau adalah makanan yang memiliki rasa yang pedas.

4. Meningkatkan keberagaman makanan tradisional Minangkabau dalam menu.

a. Mengangkat dan memperkenalkan jenis makanan tradisional Minangkabau yang ada. Potensi berbagai jenis makanan tradisional Minangkabau yang ada ditiap kabupaten yang ada di Minangkabau dapat digali dan dikumpulkan untuk kemudian dipilih sesuai dengan gastronomi internasional.

b. Memodifikasi produk-produk yang sudah ada dengan memperbaiki penampilan, menyempurnakan produk makanan tradisional Minangkabau 
ataupun menciptakan menu makananMinangkabau yang baru dengan tidak menghilangkan karakter bumbu makanan tradisional Minangkabau itu sendiri.

5. Memperbaiki dan menjaga konsistensi rasamakanan tradisional Minangkabau.

a. Membuat standard resep makanan tradisional Minangkabau. Rasa yangtidak konsisten terutama disebabkan oleh karena belum adanya suatu standar dalam pembuatan makanan tradisional Minangkabau sehingga ada perbedaan penggunaan bahan dan metode pengolahan dari masing-masing juru masak. Dengan adanya suatu standarisasipada makanan tradisional Minangkabau diharapkan dapat mengatasi kualitas rasa yang berbeda.

b. Peningkatan kualitas SDM. Pelatihan merupakan salah satu cara yang dapat dilakukan untuk meningkatkan kualitas SDM. Perusahaan perlu untuk memberikan pelatihan-pelatihan makanan tradisional Minangkabau kepada juru masak. Pelatihan makanan tradisional Minangkabau diharapkan mampu menghasilkan juru masak makanan tradisional Minangkabau yang lebih profesional sehingga diharapkan mampu untuk meningkatkan kualitas produk yang dihasilkan.

\section{Kesimpulan}

Sumatera Barat atau di sebut juga dengan Minangkabau sangat terkenal akan kulinernya, dan sangat kas dan sulit di tiru oleh daerah lain. Penelitian ini telah menghasilkan strategi desain pengembangan makanan tradisional Minangkabau dengan memanfaatkan keunggulan dan kelemahan dari beberapa faktor ekternal maupin internal.

\section{Referensi}

[1] David, F. R. 2006. Strategic Management: Concepts (Ichsan Setiyo Budi. Pentj.) Jakarta: PT.Salemba Empat.

[2] Departemen Perdagangan Republik Indonesia, Pengembangan Ekonomi Kreatif Indonesia, 2025, Jakarta 2008

[3] Departemen Pendidikan Nasional. (2003). Kamus Besar Bahasa Indonesia, Edisi Ketiga,Jakarta: Balai Pustaka

[4] Ernayanti, dkk. 2003. Ensilopedi Makanan Tradisional di Pulau Jawa dan Pulau Madura. Deputi bidang pelestarian dan pengembangan kebudayaan, asdep. Urusann epercayaan terhadap Tuhan Yang Maha Esa. Jakarta: Proyek pelestarian danpengembangan tradisi dan kepercayaan.

[5] http://travel.cnn.com/explorations/eat/readers-choice-worlds-50-mostdelicious-foods-012321

[6] Kotler, P., Bowen, J., Makens, J. 2002. Pemasaran Perhotelan dan Kepariwisataan. Jilid II Edisi Bahasa Indonesia. Jakarta: Pearson Education Asia Ptc. Ltd dan PT.Prenhallindo. 
[7] Rangkuti, F, 2006. Analisis SWOT, Tehnik Membedah Kasus Bisnis-Reorientasi Konsep Perencanaan Strategis Untuk Menghadapi Abad 21. Cetakan ke 14. Gramedia Pustaka Utama. Jakarta. 